Agronomy Journal of Nepal, (Agron JN) Vol. 1: 2010

\title{
Participatory variety slection of cold tolerant rice in the western hills of Nepal
}

TB Karki, KB Koirala and SB BK

Regonal Agricutural Research Station (RARS), Lumle, NARC

\begin{abstract}
To verify and up scale promising cold tolerant rice genotypes in the western hills, participatory variety selection (PVS) activities viz; coordinated farmer's field trials (CFFTs), FFTs prepared from Lumle , farmers' acceptance tests (FATs), larger plot demonstrations, and upscaling activities were conducted during 2008 to 2009. Yield and yield related parameters considering farmers' preferences were also recorded and analyzed for PVSs under FATs. In 2008, genotypes NR10481-B-11-1-1-1, NR10479-B-33-2-1-1 and NR10482-B-10-3-2-2 had been preferred by farmers because of high grain yield and desired parameters. In 2008, grain yield of Machapuchhre-3, Chhomrong Dhan, and Lumle 5- 2 over yielded Farmers' Local (2.2 mt/ha) by 83, 89 and 81\%, respectively whereas in 2009 , grain yield increment of Machapuchhre- 3, Chhomrong Dhan, Lumle- 2, and Chandannath-3 over Farmers' Local $(2.1 \mathrm{t} / \mathrm{ha})$ was $98 \%, 97 \%, 1078 \%$ and $49 \%$, respectively. Farmers of upper high hills (>2000-m) and high hills (1500-2000-m) preferred Chandannath-3, Machapuchhre- 3, and Chhomrong Dhan while Lumle-2 was liked by farmers of mid hills (1000-1500-m )
\end{abstract}

Key words: Cold tolerant, rice variety, participatory variety selection, hills

\section{Introduction}

Participatory technology development offers a way forward through active and decision making involvement of farmers in every stage of technology development. Developing technologies appropriate to hills of Nepal is perhaps the greatest challenge of agriculture research. It is complicated by a number of factors, like diverse agro-ecological environment, complex farming systems, and varied socio-economic circumstances. The issue is not just to produce more and different types of technologies, but to select the right types of technologies at right time and place. Therefore, it is very important that the technology generated at various research stations should be verified biologically and socio-economically over a wide range of environments so as to take account of the complexity and diversity of hill farming systems (Karki et al., 2007).

Area, production and productivity of rice in the western hills is 136769 ha, $370072 \mathrm{mt}$ and $2706 \mathrm{Kg} / \mathrm{ha}$ (MoAC, 2009). In the mid to high hills of Nepal, mostly cold resistant genotypes of rice are grown. The national average yield of rice is only $2907 \mathrm{~kg} / \mathrm{ha}$. Thus, the country's average productivity is very low compared to the average productivity of other Asian countries (Yoshida, 1983). There are a number of factors limiting rice yield. Low temperature has been among the important factors limiting rice production in the hills and high hills of Nepal. Effects of blasts, sheath rots, gundhi bug, borer, drought and poor nutrient management also cause a significant yield loss (LARC, 1997). Chilling injury in rice is common in Nepal in high altitude areas (i.e. $>1000 \mathrm{~m}$ ). About $26 \%$ are grown in temperate areas of 1000-2000 meter above the sea level. (www.idrc.ca/en/ev.), and spikelet sterility caused by chilling injury is a major constraints above $1500 \mathrm{~m}$, limiting both the area of production and the length of the crop maturity. Very few varieties inlcuding Chhomrong Dhan (CD), Machhapuchre-3, Chandannath-1 and Chandannath-3 and 
Palung-2 have been adopted so far by farmers as chilling tolerant cultivars. Many other released cold tolerant varieties are obsolete and are not in cultivation. Screening of internationally known cold tolerant materials at Lumle $(1450 \mathrm{~m})$ and Chhomrong $(2000 \mathrm{~m})$ has identified lines with good chilling tolerance during vegetative growth, but which failed to produce grain because of incomplete panicle exsertion or spikelet sterility. Adoption of improved varieties in the western hills is very low i.e about $11 \%$ (LARC, 1995). Whereas, area under improved varieties is about $25 \%$ in the hills as a whole (MoAC, 2009). Endeavours in developing and recommending genotypes are inadequate to create and maintain the adequate pool of cold tolerant rice in Nepal. RARS, Lumle has been testing, verifying and disseminating the promising genotypes in the western hills, hence, an attempt has been made to include findings of various PVS programs on cold tolerant rice carried out in the western hills during 2008 and 2009.

\section{Methodology}

Outreach research program (ORP) of RARS, Lumle is based on the concept of participatory technology development (PTD), which is an interactive and actor oriented approach consisting of researchers, extensionists, farmers, community based organizations, and user communities since its' establishment in 1968. It is a practical process of bringing together the knowledge and research capacity of concerned stakeholders both from public and private sectors in an interactive way (Prasad and Karki, 2000). However, with the advancement of time, the degree and intensity of involvement of researchers, farmers and related stakeholders has been changing. The impact of participatory technology development as a thematic area of ORP, has been immensely capitalized by the farmers of western hills. Lumle's ORP has been concentrating its' PTD activities mainly on cereals. Based on the nature of the interventions and their trade-offs, an attempt has been made to highlight the general and specific methodologies of ORP in this paper. With the aim of identifying, verifying, and promoting promising genotypes of rice, various participatory varietal testing programs were carried out on and off-stations during the year 2008 and 2009. Specifically those genotypes were tested in the farmers' fields that are primarily identified in the initial yield trials. Genotypes that were found to be superior in advanced yield trials were further tested and verified in the relatively larger plots as CFFTs, FFTs and FATs.

Manuring was done with 80:40:30 Kg NPK/ha along with FYM $10 \mathrm{t} /$ ha. Planting geometry was used as $25 \mathrm{~cm} \times 15 \mathrm{~cm}$. Thirty days old seedlings were transplanted with 2-3 seedlings/hill. CFFTs on cold tolerant rice was carried out in Myagdi and Kaski districts keeping five genopypes during the year 2008. Five set of FFTs assembled by Lumle on cold tolerant rice genotypes was carried out in the high hills of Myagdi. Three superior genotypes selected from the previous year's varietal trials were tested under FATs along with the traditionally grown improved varieties during the year 2008. Similarly, 4 superior genotypes selected from the varietal trials of the year 2008 as well as local varieties were tested under FAT during 2009 as well. CFFTs and FFTs were replicated three times i.e farmer as a replication in each location. The experiment was laid out in RCB design having the individual plot size of $6 \mathrm{~m}^{2}$. Thirty sets of each improved genotypes were compared with the existing Farmers' Local under FATs of cold tolerant rice in Kaski, Baglung and Myagdi districts. The area for each genotype under FAT was $250-\mathrm{m}^{2}$ in both the years. Observations were recorded mainly on grain yield and related parameters along with socioeconomic aspects. Farmers' criteria of selecting the improved genotypes were taken into consideration while evaluating the genotypes during farmers' field days at crop maturity stage and post harvest stage. 


\section{Results and discussion}

\section{CFFTs on high hill rice}

Of the recorded attributes, highly significant variation was found for grain yield and plant height having the highest grain yield for NR10481-B-11-1-1-1 followed by NR10479-B-33-2-1-1 and NR10482-B-103-2-2 (Table 1). The tallest tiller was expressed by NR10481-B-11-1-1-1 and NR10479-B-33-2-1-1 and the shortest by NR10562-B-7-5. None of the tested genotypes varied significantly for crop duration, straw yield and numbers of panicles per unit area (Table 1). So, there is an opportunity to select varieties with higher grain yield without compromising the crop duration. Since, the crop duartion is one of the major criterias of rice varietal selection. Panicles per square meter were directly affected by grain yield. Major yield contributing attribute for high hill rice genotypes was found to be cold tolerance and disease resistance (Bhandari et al., 2001).

Table 1. Performance of the rice genotypes in CFFTs-high hill at RARS Lumle in 2008

\begin{tabular}{llllllll}
\hline SN & Genotypes & $\begin{array}{l}\text { Grain yield } \\
\text { (kg/ha) }\end{array}$ & $\begin{array}{l}\text { Flowering } \\
\text { days }\end{array}$ & $\begin{array}{l}\text { Maturity } \\
\text { days }\end{array}$ & $\begin{array}{l}\text { Plant } \\
\text { height } \\
\text { (cm) }\end{array}$ & $\begin{array}{l}\text { Straw } \\
\text { yield } \\
\text { (t/ha) }\end{array}$ & $\begin{array}{l}\text { Panicles/ } \\
\mathbf{m}^{\mathbf{2}}\end{array}$ \\
\hline 1 & NR10481-B-11-1-1-1 & 4765 & 110 & 145 & 127 & 13.3 & 228 \\
2 & NR10482-B-10-3-2-2 & 4358 & 110 & 145 & 122 & 14.9 & 261 \\
3 & NR10479-B-33-2-1-1 & 4506 & 111 & 146 & 127 & 14.3 & 239 \\
4 & NR10562-B-7-5 & 3075 & 111 & 146 & 108 & 12.4 & 256 \\
5 & Chandannath-3 (Check) & 4022 & 111 & 146 & 119 & 13.8 & 233 \\
& & & & & & \\
\hline Grand mean & 4145 & 110.6 & 145.5 & 120.6 & 13.71 & 243.3 \\
${ }^{a}$ F test & $* *$ & NS & NS & $* *$ & NS & NS \\
CV\% & 6.4 & 1.7 & 1.2 & 3.5 & 14.4 & 11.7 \\
LSD (0.05) & 499.7 & - & - & 7.92 & - & - \\
\hline
\end{tabular}

$\mathrm{a} *, * *$, and NS indicate significant at $\mathrm{P}<0.05,0.01$ and not significant, respectively

\section{FFT on cold tolerant rice in 2008}

A set of FFT assembled and tested by Lumle during 2008 at high hill of Myagdi revealed that genotype differed only for grain and straw yields. Lumle 5-1 produced significantly higher yield $(4231 \mathrm{Kg} / \mathrm{ha})$ followed by Lumle-2 (3847 kg/ha) and LR- 91006 (2980 kg/ha). Whereas, Farmers' Local produced the lowest yield of $1102 \mathrm{~kg} / \mathrm{ha}$. Lumle 5-1 also recorded significantly high straw yield of (11 t/ha) followed by Lumle- 2 and LR-91006 with 9.0 and 9.0 t/ha respectively. Farmer's Local produced the lowest straw yield among the tested genotypes. No variation for crop duration was recorded among five genotypes during 2008 (Table 2). The higher yields of improved varieties might be due to the multiple resistances to cold, sheath blight and blast diseases (Sthapit et al. 1994). Lumle-2, similar to Machapuchhre 3 as better to cold tolerant is producing higher yield and becoming popular among the hill farmers (www.bioversityinternational.org). Similarly, as reported in WWW: 1prapp14.fao.org during 2004, the grain yield and cold tolerance attributes of the genotypes LR-91006 and Lumle5-2 have been explicitly mentioned. 
Table 2. Performance of selected genotypes under farmers' field trial in high hill in 2008

\begin{tabular}{llllllll}
\hline SN & Genotypes & $\begin{array}{l}\text { Maturity } \\
\text { days }\end{array}$ & $\begin{array}{l}\text { Plant } \\
\text { height } \\
\text { (cm) }\end{array}$ & $\begin{array}{l}\text { Grain } \\
\text { fertility } \\
\mathbf{( \% )}\end{array}$ & $\begin{array}{l}\mathbf{1 0 0 0} \text { grain } \\
\text { weight }(\mathbf{g})\end{array}$ & $\begin{array}{l}\text { Grain } \\
\text { yield } \\
\text { (kg/ha) }\end{array}$ & $\begin{array}{l}\text { Straw yield } \\
\text { (t/ha) }\end{array}$ \\
\hline 1 & Lumle 5-2 & 159 & 116 & 95.4 & 29 & 4231 & 11 \\
2 & Lumle- 2 & 161 & 132 & 78.4 & 29 & 3847 & 9 \\
3 & LR 91006 & 160 & 129 & 92.9 & 30 & 2980 & 9 \\
4 & Chhomrong Dhan & 160 & 114 & 91.2 & 28 & 1990 & 6 \\
$5 \quad$ Farmer's Local & 164 & 118 & 92.3 & 27 & 1102 & 5 \\
Grand mean & 160 & 121.5 & 90.1 & 28.2 & 2830 & 8 \\
a F test & NS & NS & NS & NS & $*$ & $*$ \\
CV\% & 1.3 & 7.2 & 11.2 & 4.2 & 20.4 & 15.7 \\
SEM(0.05) & - & - & - & - & 576.3 & 1.2 \\
\hline
\end{tabular}

$\mathrm{a} *, * *$, and $\mathrm{ns}$ indicate significant at $\mathrm{P}<0.05,0.01$ and not significant, respectively

\section{FAT on cold tolerant rice in 2008}

Machapuchhre-3, Chhhomrong Dhan and Lumle-2 were preferred by farmers over their Local because of increased grain yield with higher head rice recovery by volume and higher straw yield. Yield increment of Machapuchhre-3, Chhomrong Dhan and Lumle-2 over Farmers' Local was 83, 89 and 81, \% respectively during 2008 (Table 3). Despite having the high grain and straw yield with shiny-white grain of Machapuchhre-3, its' susceptibility to shattering was the problem faced by the hill farmers.

Table 3. Performance of cold tolerant rice in FATs at Baglung and Myagdi districts in 2008

\begin{tabular}{llllll}
\hline Genotype & $\begin{array}{l}\text { Days to } \\
\text { maturity }\end{array}$ & $\begin{array}{l}\text { Plant height } \\
(\mathbf{c m})\end{array}$ & $\begin{array}{l}\text { Straw yield } \\
(\mathbf{t} / \mathbf{h a})\end{array}$ & $\begin{array}{l}\text { Grain yield } \\
(\mathbf{t} / \mathbf{h a})\end{array}$ & yield increment* \\
\hline Machhapuchre-3 & 128 & 122 & 11.5 & 4.5 & $2.13(89 \%)$ \\
Farmer's Local & 135 & 134 & 9.3 & 2.3 & - \\
Chhomrong Dhan & 133 & 135 & 12.4 & 4.6 & $2.19(89 \%)$ \\
Farmers' Local & 136 & 142 & 8.7 & 2.4 & - \\
Lumle- 2 & 131 & 142 & 9.6 & 4.1 & $1.85(81 \%)$ \\
Farmer's Local & 136 & 143 & 8.4 & 2.2 & - \\
\hline
\end{tabular}

Note: * over Local

\section{FAT on cold tolerant rice in 2009}

All the varieties tested were liked by the farmers over their Local for their high grain yield with optimum straw yield. However, several criteria were tested while asking farmers during farmers' field day and post harvest handling. Yield increment of Machapuchhre-3, Chhomrong Dhan, Lumle-2 and Chandannath-3 over Farmers Local was $97.9 \%, 97.2 \%, 107.9 \%$ and 49.1\%, respectively during 2009 (Table 4). Despite having the high grain and straw yield with shiny-white grain in Machapuchhre- 3, its' susceptibility to shattering was the problem faced by hill farmers. Basnet (2008) also reported that the Chandannath-3 is becoming popular in Jumla and yield increase is more than 50\% as compared to Jumli Marshi and can be grown successfully in the higher western hills. 
Table 4. Performance of cold tolerant rice in FAT at Baglung and Myagdi districts in 2009

\begin{tabular}{llllll}
\hline Genotype & $\begin{array}{l}\text { Days to } \\
\text { maturity }\end{array}$ & $\begin{array}{l}\text { Plant height } \\
(\mathbf{c m})\end{array}$ & $\begin{array}{l}\text { Straw Yield } \\
(\mathbf{t} / \mathbf{h a})\end{array}$ & $\begin{array}{l}\text { GrainYield } \\
(\mathbf{t} / \mathbf{h a})\end{array}$ & $\begin{array}{l}\text { Yield } \\
\text { increment* }\end{array}$ \\
\hline Machhapuchre-3 & 132 & 115.8 & 10 & 4.2 & $2.09(99 \%)$ \\
Farmer's Local & 139 & 127.4 & 9 & 2.1 & - \\
Chhomrong Dhan & 137 & 121.5 & 10 & 4.3 & $2.16(97 \%)$ \\
Farmer's Local & 140 & 134.3 & 8 & 2.2 & - \\
Lumle-2 & 135 & 130.1 & 11 & 5.1 & $3.65(108 \%)$ \\
Farmer's Local & 136 & 133.2 & 8 & 2.4 & - \\
Chandannath-3 & 146 & 125.4 & 11 & 4.7 & $1.57(49 \%)$ \\
Farmer's Local & 135 & 120.5 & 8 & 3.2 & - \\
\hline
\end{tabular}

Note: * over Local

\section{Farmers' reactions over the improved cold tolerant rice genotypes}

The response of thirty responding farmers for each improved genotype as compared the existing Farmers' Local is illustrated (Table 5). Higher grain yields were reported for Chhomrong Dhan and Machapichhre 3 where as Lumle 2 and Chandannath-3 were reported to be similar in producing the grain yield. Among the various factors that determine the fate of the tersted varieties were grain and straw yield, good milling recovery and diseases. Chhomrong Dhan, Machapuchhre 3 and Chandannath-3 were found to be resistant to diseases (rice blast). Chandannath-3 performed better in the upper high hills of Baglung, Myagdi and Kaski. Chhomrong Dhan, Machapuchhre 3 and Lumle 2 performed well under mmid high hills, lower high hills and mid hills of Baglung, Myagdi and Kaski districts (Table 5).

Table 5. Percentage of respondents for selecting rice varieties against their attributes in Baglung, Myagdi and Kaski districts

\begin{tabular}{|c|c|c|c|c|}
\hline \multirow[t]{2}{*}{ Attributes for selection } & \multicolumn{4}{|c|}{ Percentage of respondent for the variety } \\
\hline & Chhomrong Dhan & Machhapuchhre- 3 & Lumle- 2 & Chandannath-3 \\
\hline High straw yield & 35 & 25 & 25 & 20 \\
\hline High grain yield & 45 & 40 & 35 & 35 \\
\hline Good cooking quality & 5 & 20 & 35 & 30 \\
\hline Good milling recovery & 5 & 15 & 20 & 15 \\
\hline Good taste & 16 & 20 & 25 & 30 \\
\hline Palatable straw & 15 & 30 & 30 & 20 \\
\hline Cold tolerance & 25 & 20 & 10 & 30 \\
\hline Early maturity & - & - & 15 & 15 \\
\hline Long sustaining food & 15 & 10 & 10 & 15 \\
\hline $\begin{array}{l}\text { Low management } \\
\text { requirement }\end{array}$ & 20 & 10 & 10 & 5 \\
\hline Lodging resistant & - & 5 & 25 & 20 \\
\hline Good in rainfed condition & 32 & 30 & 20 & 15 \\
\hline Good for making mats & 15 & 35 & 10 & 10 \\
\hline Disease resistant & 10 & 15 & 15 & 10 \\
\hline Shattering resistant & 50 & - & 20 & 30 \\
\hline Number of respondents & 30 & 30 & 30 & 30 \\
\hline
\end{tabular}

\section{Conclusion}

Among the tested genotypes under CFFT during 2008, NR10481-B-11-1-1-1, NR10479-B-33-2-1-1 and NR 10482-B-10-3-2-2 were preferred by the farmers for their higher grain yield. Similarly, Lumle 5-1 and Lumle- 2 were found to be superior in FFT during 2008. Farmers of upper high hills and high hills preferred the variety Chandannath-3, Machapuchhre- 3 and Chhomrong Dhan. Where as and Lumle- 2 was liked by the farmers of mid hills. Group field visits, preference ranking, and monitoring are useful for assessing the varietal performance. Challenge of ever increasing demand of source seed for the cold 
tolerant varieties need to be managed by implementing the site specific community based seed production program in the hills and mountains.

\section{Acknowledgements}

The authors express gratitude to the Nepal Agricultural Research Council, Singhadurbar Plaza. They are equally thankful to the collaborating farmers of RCA, Lumle. Special thanks are also due to the outrech research staff of RARS, Lumle for their cooperation in successfully accomplishing the field work. The authors are indebted to reviewing and editing of this paper by Dr. MN Paudel, Chief, Outreach Research Division, NARC.

\section{Reference}

Basnet, BMS. 2008. Environment friendlt technologies for increasing rice productivity. The Journal of Agriculture and Environment Vol: 9, Jun. 2008.

Bhandari, H.S., R.B. Prasad and S. Sharma, 2001. In: Proceedings of 21st National Summer Crops Research Workshop (Rice Research Reports), March 17-19, 1998. pp: 46-59

Karki, T.B., Pandey, Y.R., Koirala, K.B., BK, S.B and Ghimire, K.H. 2007. On-Farm Agricultural Research: An Experience of Lumle. Proceedings of the 8th National Outreach Research Workshop, 19-20 June, 2007. NARC, Nepal.

LARC, 1995 The adoption, diffusion and incremental benefit of technologies for crops, horticulture, livestock and forestry in the western hills of Nepal. LARC Occasional Paper No. 95/1. Kaski, Nepal. Lumle Agricultural Research Centre.

LARC, 1997. The strategy for rice Research. LARC Strategy Paper No. 97/1. Kaski, Nepal. Lumle Agricultural Research Centre.

Ministry of Agriculture. 2008. Statistical Information on Nepalese Agriculture. Government of Nepal, MOAC. Agribusiness promotion and Statistics Division, Singhadurbar, Kathmandu, Nepal.

Sthapit, BR., Joshi, KD and Witcombe, JR. 1994. Farmers participatory high altitude rice breeding in Nepal:providing choice and utilizing farmers experties. The International Development research Centre.

www.idrc.ca/en/ev.

www.bioversityinternational.org/.

www.1prapp14.fao.org/

Yoshida, S. 1983. Rice: In potential productivity of field crops under different environments. International Rice Researc Institute (IRRI), Philippines, pp 103-127. 